\title{
PENINGKATAN KEMAMPUAN GURU DALAM MEMANFAATKAN LINGKUNGAN SEKOLAH SEBAGAI SUMBER BELAJAR MELALUI DISKUSI KELOMPOK KERJA GURU DI SDN 6 RAJA TAHUN PELAJARAN 2019/2020 \\ Ncreasing Teachers' Capabilities In Using The School Environment AS A Learning Source Through Teacher Work Group Discussion At SDN 6 Raja Academic Year 2019/2020
}

\section{MUJIHARTONO, SDN 6 Raja}

*Kalimantan Tengah, Indonesia.

\begin{abstract}
Abstrak
setrategi pembelajaran yang sesuai dengan hal tersebut adalah pembelajaran dengan pendekatan Pakem.Dengan memanfaatkan lingkungan sekolah sebagai sumber belajar maka implementasi pembelajaran pakem akan memungkinkan siswa bisa mengembangkan kreativitas, motivasi dan partisipasinya dalam pembelajaran . Dari hasil pantauan calon peneliti selaku pengawas sekolah, selama ini para guru di SDN 6 RAJA , sangat jarang dan bahkan tidak pernah memanfaatkan lingkungan sekolah sebagai sumber belajar.

Begitu pula dalam KKG, kemampuan guru berdiskusi masih kurang aktif dan kreatif, sehingga kemampuan guru memanfaatkan lingkungan sekolah sebagai sumber belajar belum baik. Rumusan Masalah adalah: I. Apakah dengan diskusi Kelompok Kerja Guru (KKG) dapat meningkatkan kemampuan guru dalam memanfaatkan lingkungan sekolah sebagai sumber belajar di SDN 6 RAJA

2. Apakah kelemahan dan kelebihan pelaksanaan diskusi Kelompok Kerja Guru (KKG) terhadap peningkatan kemampuan guru dalam memanfaatkan lingkungan sekolah sebagai sumber belajar di SDN 6 RAJA

Penelitian ini dirancang dalam bentuk Penelitian Tindakan Sekolah yang direncanakan dilaksanakan dalam dua siklus,ndimana setiap siklusnya dilaksanakan dalam dua sampai tiga kali pertemuan. Adapun subyek penelitian ini adalah guru-guru di SDN 6 RAJA yang terdiri dari enam orang guru kelas dan dua orang guru bidang studi.
\end{abstract}

Hasil Penelitian : Pada siklus I nilai diperoleh dari sikap guru 79,38 katagori"cukup,sedangkan pada siklus II nilai rata-rata yang diperoleh adalah 84,88 , katagori "baik",nilai rata-rata yang diperoleh dari penilaian skenario pembelajaran pada siklus I yaitu 78,75 katagori "cukup" sedangkan pada siklus II nilai rata-rata yang diperoleh adalah 82,50 , pada siklus I yaitu 78,33 katagori "cukup", sedangkan pada siklus II nilai yang diperoleh adalah 82,08 katagori "baik".

learning strategy that suits this is learning with the Pakem approach. By utilizing the school environment as a learning resource, the implementation of standard learning will allow students to develop creativity, motivation and participation in learning. From the observations of prospective researchers as school supervisors, so far the teachers at SDN 6 RAJA, very rarely and never even use the school environment as a learning resource.

Likewise in the KKG, the ability of teachers to discuss is still less active and creative, so that the ability of teachers to use the school environment as a learning resource is not good. The formulation of the problem is: I. Can the discussion of the Teacher Working Group (KKG) improve the ability of teachers to utilize the school environment as a learning resource at SDN 6 RAJA

2. What are the weaknesses and strengths of the implementation of the Teacher Working Group (KKG) discussion on improving the ability of teachers to utilize the school environment as a learning resource at SDN 6 RAJA

This research is designed in the form of School Action Research which is planned to be carried out in two cycles, where each cycle is carried out in two to three meetings. The subjects of this study were teachers at SDN 6 RAJA which consisted of six classroom teachers and two study teachers.

Research Results: In the first cycle the value obtained from the teacher's attitude was 79.38 in the "enough" category, while in the second cycle the average value obtained was 84.88 , the "good" category, the average value obtained from the assessment of learning scenarios in the cycle The first cycle is 78.75 "enough" category while in the second cycle the average value obtained is 82.50 , in the first cycle is 78.33 "enough" category, while in the second cycle the value obtained is 82.08 "good" category. "

(C) 202IThe Authors. Published by Institute for Research and Community Services Universitas Muhammadiyah Palangkaraya. This is Open Access article under the CC-BY-SA License (http://creativecommons.org/licenses/by-sa/4.0/). 


\section{A. Latar Belakang Masalah}

Untuk itu sesuai Kurikulum Tingkat Satuan Pendidikan (KTSP) yang berlaku sekarang ini, memerlukan strategi baru terutama dalam kegiatan pembelajaran. Pendekatan pembelajaran yang sebelumnya lebih banyak didominasi oleh peran guru (teacher centered) diperbaharui dengan sistem pembelajaran yang berpusat pada siswa (student centered). Dalam implementasi KTSP guru harus mampu memilih dan menerapkan model, motode atau setrategi pembelajaran yang sesuai dengan karakteristik materi sehingga mampu mengembangkan daya nalar siswa secara optimal.Dengan demikian dalam pembelajaran guru tidak hanya terpaku dengan pembelajaran di dalam kelas, melainkan guru harus mampu melaksanakan pembelajaran dengan motode yang variatif.

Disamping itu sesuai dengan pendekatan PAKEM (Pembelajaran Aktif Kreatif dan Menyenangkan), guru harus mampu menghadapkan siswa dengan dunia nyata sesuai dengan yang dialaminya sehari-hari. Salah satu setrategi pembelajaran yang sesuai dengan pendekatan Pakem yang memungkinkan bisa mengembangkan kreativiats, motivasi dan partisipasi siswa dalam pembelajaran adalah dengan memanfaatkan lingkungan sekolah sebagai sumber belajar. Hal ini juga sesuai dengan salah satu pilar dari pendekatan contekstual yaitu masyarakat belajar (learning commonity). Untuk mencapai tujuan tersebut, salah satu cara belajar yang disarankan dalam KTSP sebagai upaya mendekatkan aktivitas belajar siswa pada berbagai fakta kehidupan sehari-hari di sekitar lingkungan siswa. Memanfaatkan lingkungan sekolah sebagai sumber belajar menjadi alternatif setrategi pembelajaran untuk memberikan kedekatan teoritis dan praktis bagi pengembangan hasil belajar siswa secara optimal. Ekowati (200I) mengatakan, memanfaatkan lingkungan sekolah sebagai sumber belajar merupakan bentuk pembelajaran yang berfihak pada pembelajaran melalui penggalian dan penemuan (experiencing) serta keterkaitan (relating) antara materi pelajaran dengan konteks pengalaman kehidupan nyata melalui kegiatan proyek. Pada pembelajaran dengan setrategi ini guru bertindak sebagai pelatih metakognitif yaitu membantu pebelajar dalam menemukan materi belajar, mengintegrasikan pengetahuan dan ketrampilan dalam pembuatan laporan dan dalam penampilan hasil dalam bentuk presentasi.

Dari hasil pantauan calon peneliti selaku pengawas sekolah, selama ini para guru masih sangat jarang memanfaatkan lingkungan sekolah sebagai sumber belajar. Lingkungan sekolah tidak lebih hanya digunakan sebagai tempat bermain-main siswa pada saat istirahat. Kalau tidak jam istirahat, guru lebih sering memilih mengkarantina siswa di dalam kelas, walaupun misalnya siswa sudah merasa sangat jenuh berada di dalam kelas.

Seperti observasi awal yang dilakukan di SDN 6 Raja , guru-guru di sekolah tersebut memanfaatkan lingkungan sekolah sebagai sumber belajar hanya dua sampai tiga kali dalam satu semester. Guru lebih sering menyajikan pelajaran di dalam kelas walaupun materi yang disajikan berkaitan dengan lingkungan sekolah. Dari wawancara yang dilakukan calon peneliti, sebagian besar guru mengaku enggan mengajak siswa belajar di luar kelas, karena alasan susah mengawasi. Selain itu ada guru yang menyampaikan bahwa mereka tidak bisa dan tidak tahu dalam memanfaatkan lingkungan sekolah sebagai sumber belajar.

Untuk mengatasi hal itu perlu adanya diskusi kelompok diantara para guru kelas dalam bentuk KKG untuk mendiskusikan masalah pemanfaatan lingkungan sekolah sebagai sumber belajar.

Dalam kegiatan diskusi tersebut para guru bisa membagi pengalaman dalam pemanfaatan lingkungan sekolah sebagai sumber belajar untuk mencapai hasil belajar yang optimal. Penelitian Nur Mohamad dalam Ekowati (200I) menunjukkan diskusi kolompok memiliki dampak yang amat positif bagi guru yang tingkat pengalamannya rendah maupun yang tingkat pengalamannya tinggi.

Bagi guru yang tingkat pengalamannya tinggi akan menjadi lebih matang dan bagi guru yang tingkat pengalamannya rendah akan menambah pengetahuan. Keunggulan diskusi kelompok melalui KKG adalah keterlibatan guru bersifat holistic dan konprehensip dalam semua kegiatan. Dari segi lainnya guru dapat menukar pendapat, memberi saran, tanggapan dan berbagai reaksi sosial dengan teman seprofesi sebagai peluang bagi mereka untuk meningkatkan kemampuan dan pengalaman.

\section{B. Identifikasi Masalah.}

Berdasarkan latar belakang tersebut di atas, serta hasil pengamatan peneliti melalui supervisi,maka dapat diidentifikasi masalahnya sebagai berikut:

I. Pendekatan pembelajaran lebih banyak didominasi oleh peran guru, dan guru satu-satunya sumber belajar,selain buku paket.

2. Pembelajaran yang dikembangkan di kelas - kelas kelihatannya lebih ditekankan pada pemikiran reproduktif, menekankan pada hafalan dan mencari satu jawaban benar terhadap soal-soal yang diberikan

3. Dalam kegiatan pembelajaran guru belum mampu menerapkan model, motode atau setrategi pembelajaran yang sesuai dengan karakteristik materi yang diajarkan sehingga kurang mengembangkan daya nalar siswa secara optimal.

4. Dalam proses pembelajaran guru sangat jarang memanfaatkan lingkungan sekolah sebagai sumber belajar,walaupun materi pelajaran ada kaitannya dengan lingkungan sekolah.

5. Kegiatan Kelompok Kerja Guru (KKG) belum dimanfaatkan dan dilaksanakan secara optimal.

\section{Rumusan Masalah}

Berdasarkan identifikasi masalah diatas,maka dalam penelitian tindakan sekolah ini difokuskan pada penelitian masalah memanfaatkan lingkungan sekolah sebagai sumber belajar yang dapat dirumuskan sebagai berikut :

I. Apakah kemampuan guru dalam memanfaatkan lingkungan sekolah sebagai sumber belajar dapat ditingkatkan melalui diskusi Kelompok Kerja Guru di SDN 6 Raja?.

2. Apakah kelemahan dan kelebihan pelaksanaan diskusi Kelompok Kerja Guru (KKG) terhadap peningkatan kemampuan guru dalam memanfaatkan lingkungan sekolah sebagai sumber belajar di SDN 6 Raja ?

\section{Pemecahan Masalah}


Berdasarkan pada rumusan masalah diatas, dapat ditentukan hipotesis tindakan dalam penelitian tindakan sekolah ini adalah : Diskusi Kelompok Kerja Guru (KKG), dapat meningkatkan kemampuan guru dalam memanfaatkan lingkungan sekolah sebagai sumber belajar di SDN 6 Raja

E. Tujuan dan Manfaat Penelitian

I. Tujuan Penelitian

Berdasarkan rumusan masalah di atas, maka tujuan dari dilaksanakan penelitian tindakan sekolah ini adalah :

a. Untuk meningkatkan kemampuan guru dalam memanfaatkan lingkungan sekolah sebagai sumber belajar melalui diskusi Kelompok Kerja Guru (KKG) di SDN 6 Raja

2. Manfaat Penelitian

Hasil Penelitian Tindakan Kelas ini diharapkan memberikan manfaat yang berarti bagi :

a. Guru, dapat menyempurnakan metode pembelajaran yang diterapkan di sekolah sehingga dapat meningkatkan kreativiats, motivasi dan hasil belajar siswa.

b. Sekolah, dapat memberikan motivasi bagi guru-guru yang lain untuk menyempurnakan metode dan setrategi pembelajaran yang diterapkan di sekolah dalam upaya meningkatkan hasil belajar siswa.

c. Pengawas sekolah, dapat membantu dalam membimbing dan pengawas guru dalam pelaksanaan tugasnya sehingga dapat meningkatkan kompetensi dan profesionalisme guru.

\section{KAJIAN PUSTAKA}

\section{A. Pemanfaatan Lingkungan Sekolah sebagai Sumber Belajar}

Sumber belajar masyarakat dapat digunakan untuk kepentingan proses pembelajaran sains, ilmu sosial dan yang lainnya, salah satunya melalui survei wilayah. Melalui survei wilayah siswa akan menemukan sumber belajar di masyarakat sehingga mampu menumbuhkan motivasi untuk memperkaya nilai-nilai hasil belajar guna dapat meningkatkan pemahaman dan peningkatan materi pelajaran. (Sarman, 2005 : 3)

Nilai-nilai kegunaan sumber belajar masyarakat adalah : (I) menghubungkan kurikulum dengan kegiatankegiatan masyarakat akan mengembangkan kesadaran dan kepekaan terhadap masalah sosial; (2) menggunakan minatminat pribadi peserta didik akan menyebabkan belajar lebih bermakna baginya;

(3) mempelajari kondisi-kondisi masyarakat merupakan latihan berpikir ilmiah (scientif methode); (4) mempelajari masyarakat akan memperkuat dan memperkaya kurikulum melalui pelaksanaan praktis didalam situasi sesungguhnya; (5) peserta didik memperoleh pengalaman langsung yang kongkrit, realistis dan verbalisme. (Douglas dan Mill dalam Rusyan 2001 : 152)

Pemanfaatan lingkungan sekolah sebagai sumber belajar mengarahkan anak pada peristiwa atau keadaan yang sebenarnya atau keadaan yang alami sehingga lebih nyata, lebih faktual dan kebenarannya lebih dapat dipertanggungjawabkan.
Manfaat nyata yang dapat diperoleh dengan memanfaatkan lingkungan ini adalah : (I) menyediakan berbagai hal yang dapat dipelajari anak, (2) memungkinkan terjadinya proses belajar yang lebih bermakna (meaningful learning), (3) memungkinkan terjadinya proses pembentukan kepribadian anak, (4) kegiatan belajar akan lebih menarik bagi anak, dan (5) menumbuhkan aktivitas belajar anak (learning aktivities). (Badru Zaman, dkk. 2005)

\section{B. Diskusi Kelompok Kerja Guru.}

Kelompok Kerja Guru (KKG) adalah bentuk kegiatan yang beranggotakan guru-guru kelas, dimana tujuan kegiatannya adalah untuk meningkatkan kemampuan dan kompetensi mereka sesuai kelas yang dipegang. Bentuk kegiatan KKG bisa berupa diklat, simulasi, diskusi atau yang lainnya.

Kemudian diskusi kelompok adalah suatu kegiatan belajar yang dilakukan secara bersama-sama. Diskusi kelompok pada dasarnya memecahkan persoalan secara bersama-sama. Artinya setiap anggota turut memberikan sumbangan pemikiran dan pendapat dalam memecahkan persoalan tersebut. Diskusi kelompok adalah suatu kegiatan belajar untuk memecahkan persoalan secara bersama-sama, sehingga akan memperoleh hasil yang lebih baik. (Tabrani dan Daryani dalam Kasianto,2004)

Berdasarkan uraian diatas, dapat disimpulkan bahwa diskusi kelompok adalah suatu proses usaha yang dilakukan individu untuk memperoleh perubahan tingkah laku sebagai pengalaman individu dalam interaksinya dengan lingkungan yang dilakukan secara bersama-sama atau berkelompok.

Ischak.SW dan Warji R. (dalam Kasianto,2004) mengemukakan beberapa petunjuk dalam pelaksanaan diskusi kelompok, yaitu :

a. Pilihlah teman yang cocok untuk bergabung dalam belajar kelompok. Jumlah setiap kelompok terdiri dari 5 hingga 7 orang.

b. Tetapkan siapa sebagai pemimpin yang akan memimpin jalannya diskusi atau belajar kelompok.

c. Hentaskan persoalan satu persatu dengan memberi kesempatan kepada anggota untuk mengajukan pendapatnya. Dari pendapat yang masuk dikaji bersama-sama mana yang paling tepat.

(Ischak.SW dan Warji R. dalam Kasianto,2004)

Dari uraian di atas,maka di dalam pelaksanaan diskusi kelompok perlu diperhatikan pembentukan kelompok,penetapan pimpinan kelompok,penetapan masalah yang akan dibahas dan pencatatan kesimpulan hasil diskusi kelompok.

\section{METODE PENELITIAN}

\section{A. Lokasi Penelitian}

Penelitian Tindakan Sekolah ini berlokasi di SDN 6 Raja , yang ditujukan pada guru-guru kelas dan guru bidang studi.Adapun alasan utamanya adalah dari hasil pengamatan dan informasi dari guru,bahwa hampir semua guru jarang dan bahkan tidak pernah memanfaatkan lingkungan sekolah sebagai sumber belajar.

\section{B. Perencanaan Tindakan}


Bentuk tindakan dalam penelitian ini berupa supervisi (bimbingan kelompok) kepada guru-guru melalui KKG, agar mampu menyusun skenario pembelajaran dan pelaksanaan pembelajaran dengan memanfaatkan lingkungan sekolah sebagai sumber belajar secara efektif. Secara rinci bentuk tindakan dalam penelitian ini adalah :

I. Menyampaikan informasi tentang pemanfaatan lingkungan sekolah sebagai sumber belajar.

2. Membimbing guru menyusun skenario pembelajaran yang berkaitan dengan pemanfaatan lingkungan sekolah sebagai sumber belajar.
3. Membimbing guru dalam memanfaatkan lingkungan sekolah sebagai sumber belajar.

4. Membimbing guru dalam melaksanakan pembelajaran dengan memanfaatkan lingkungan sekolah sebagai sumber belajar.

Prosedur penelitian yang dilakukan adalah menggunakan model penelitian tindakan sekolah yang dikembangkan oleh Kemmis \& Taggart (2000), dimana pada prinsipnya ada empat tahap kegiatan yaitu, perencanaan tindakan (planning), pelaksanaan tindakan (action), observasi dan evaluasi proses tindakan (observation and evaluation) dan melakukan refleksi (reflecting).

Alur penelitian secara keseluruhan dapat digambarkan sebagai berikut :

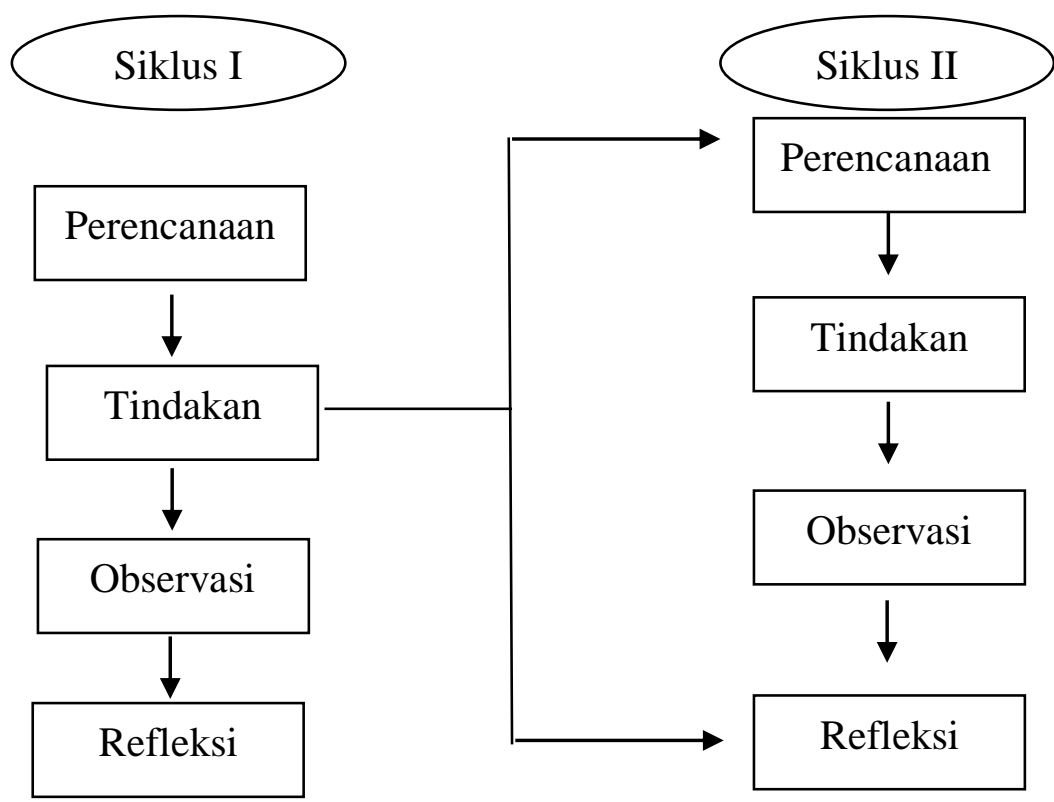

Gambar 0.I. Alur Penelitian

Secara rinci prosedur tindakan yang dilakukan adalah :

I. Membagi guru dalam dua kelompok kecil.

2. Peneliti memberi penjelasan tentang pemanfaatan lingkungan sekolah sebagai sumber belajar.

3. Guru menyusun skenario pembelajaran dengan memanfaakan lingkungan sekolah sebagai sumber belajar dalam diskusi kelompok.

4. Peneliti membimbing kelompok guru dalam menyusun skenario pembelajaran.

5. Wakil kelompok guru mempresentasikan skenario pembelajaran.

6. Peneliti memberi masukan terhadap skenario pembelajaran yang telah dibuat kelompok guru.

7. Guru melaksanakan skenario pembelajaran dalam proses pembelajaran yang sebenarnya.

8. Peneliti mengevaluasi kemampuan guru dalam mengimplementasikan skenario pembelajaran.

9. Dalam kelompok diskusi guru berbagi pengalaman terkait dengan pelaksanaan pembelajaran yang memanfaakan lingkungan sekolah sebagai sumber belajar.

10. Target yang diharapkan: a. Guru mampu membuat skenario pembelajaran dengan memanfaakan lingkungan sekolah sebagai sumber belajar.

b. Guru mampu melaksanakan pembelajaran dengan memanfaakan lingkungan sekolah sebagai sumber belajar.

c. Guru mampu berdiskusi secara aktif dan kreatif,dan mampu memanfaatkan diskusi kelompok kerja guru secara efektif dan efesien dalam memecahkan masalah yang terkait dengan kegiatan pembelajaran.

\section{Pelaksanaan Tindakan.}

\section{Siklus I}

a. Perencanaan Penelitian.

Kegiatan penelitian ini direncanakan berlangsung selama dua siklus,mulai bulan

Juli s/d bulan Agustus 2019 di SDN 6 Raja , pada jam sekolah 07.30 I2.50.

Perencanaan penelitian meliputi: 
I). Pertemuan dengan Kepala Sekolah dan guru guru, menginformasikan tentang pelaksanaan penelitian.

2). Peneliti menyiapkan skenario diskusi kelompok yang akan dilaksanakan selama proses tindakan.

3). Peneliti menyiapkan instrumen penelitian ( lembar observasi, lembar penilaian kemampuan guru).

b. Pelaksanaan Penelitian.

Pada tahap pelaksanaan merupakan tahap inti dimana pelaksanaan diskusi KKG berlangsung dengan langkah-langkah berikut.

I). Pertemuan I

a). Peneliti selaku pengawas sekolah memberi arahan umum pemanfaatan lingkungan sekolah sebagai sumber belajar

2). Pertemuan II

a). Guru melaksanakan pembelajaran dengan memanfaatkan lingkungan sekolah sebagai sumber belajar sesuai skenario pembelajaran yang dimiliki. b). Peneliti melakukan penilaian pada guru terkait dengan implementasi pembelajaran sesuai skenario yang dibuat.

3). Pertemuan III

a). Kelompok kerja guru melakukan diskusi tentang kendala-kendala pelaksanakan pembelajaran dengan memanfaatkan lingkungan sekolah sebagai sumber belajar.

b). Peneliti melakukan bimbingan dalam kelompok, terkait dengan pembelajaran yang diterapkan guru. dan merevisi skenario pembelajaran sehingga menghasilkan skenario pembelajaran yang sesuai dengan pakem.

c. Observasi dan Evaluasi

Kegiatan observasi dilaksanakan bersamaan dengan pelaksanaan tindakan yaitu pada saat diskusi KKG baik pada pertemuan I, II dan III.

Tahap observasi bertujuan untuk mengetahui kerjasama ,kreativitas,perhatian, maupun presentasi yang dilakukan guru dalam menyusun skenario pembelajaran maupun dalam melaksanakan pembelajaran dengan memanfaatkan lingkungan sekolah sebagai sumber belajar.

Pelaksanaan observasi dilakukan dengan menggunakan lembar observasi:

Tabel. 3.I.Format Observasi

\begin{tabular}{|c|c|c|c|c|c|c|}
\hline \multirow{3}{*}{ NO } & \multirow{3}{*}{ Nama Guru } & \multicolumn{4}{|c|}{ Aspek yang diobservasi } & \multirow{3}{*}{$\begin{array}{l}\text { Jumlah } \\
\text { Skor } \\
\text { Mak. } 100\end{array}$} \\
\hline & & Kerjasama & Aktivitas & Perhatian & Presentasi & \\
\hline & & $(1-10)$ & $(I-40)$ & $(I-20)$ & $(I-30)$ & \\
\hline $\mathrm{I}$ & SLP & & & & & \\
\hline 2 & PMT & & & & & \\
\hline 3 & ST & & & & & \\
\hline 4 & NST & & & & & \\
\hline 5 & NWY & & & & & \\
\hline 6 & BRD & & & & & \\
\hline 7 & DPA & & & & & \\
\hline 8 & $\mathrm{NHZ}$ & & & & & \\
\hline
\end{tabular}

Adapun skala penilaian yang digunakan adalah skala Likert dengan 5 katagori sikap yaitu:sangat tinggi, tinggi, rendah, sedang dan sangat rendah. Penilaian dilakukan dengan memberi skor pada kolom yang tesedia dengan ketentuan sebagai berikut : skor $5=$ sangat tinggi, skor $4=$ tinggi, skor 3 = sedang, skor 2 = rendah, dan skor $\mathrm{I}=$ sangat rendah.

Untuk mendapatkan nilai digunakan rumus :

$$
\mathrm{NK}=\frac{\text { Jumlah skor perolehan }}{\text { Jumlah skor maksimal }} \times 100
$$

Setelah diperoleh nilai,maka nilai tersebut ditransfer ke dalam bentuk kualitatif untuk memberikan komentar bagaimana kualitas sikap guru yang diamati dalam diskusi KKG, penyusunan skenario pembelajaran dan penilaian pelaksanaan pembelajaran dengan kriteria penilaian acuan patokan skala lima sebagai berikut:

Tabel. 3. 2. Kreteria Penilaian Acuan Patokan Skala Lima

\begin{tabular}{|c|c|l|}
\hline N & Rentang Nilai & \multicolumn{1}{c|}{ Kreteria } \\
\hline I & $90-100$ & A=Baik Sekali \\
\hline 2 & $80-89$ & B=Baik \\
\hline 3 & $65-79$ & C=Cukup \\
\hline 4 & $55-64$ & D=Kurang \\
\hline 5 & $0-54$ & E=Sangat kurang \\
\hline
\end{tabular}

Sutrisno Hadi (2000).

Tahap evaluasi dilakukan pada akhir tindakan yang bertujan untuk mengetahui tingkat kemampuan guru dalam memanfaatkan lingkungan sekolah sebagai sumber belajar. 
Pelaksanaaan evaluasi dilakukan dengan menggunakan lembar penilaian skenario pembelajaran dan lembar penilaian pelaksanaan pembelajaran sebagai berikut:

Tabel.3.3. Format Penilaian Skenario Pembelajaran

\begin{tabular}{|c|c|c|c|c|c|c|}
\hline \multirow[b]{2}{*}{ NO } & \multirow[b]{2}{*}{ Nama Guru } & \multicolumn{4}{|c|}{ Aspek yang dinilai } & \multirow{2}{*}{$\begin{array}{c}\text { Jumlah } \\
\text { Skor } \\
(I-5)\end{array}$} \\
\hline & & $\mathrm{I}$ & 2 & 3 & 4 & \\
\hline I & SLP & & & & & \\
\hline 2 & PMT & & & & & \\
\hline 3 & ST & & & & & \\
\hline 4 & NST & & & & & \\
\hline 5 & NWY & & & & & \\
\hline 6 & BRD & & & & & \\
\hline 7 & DPA & & & & & \\
\hline 8 & $\mathrm{NHZ}$ & & & & & \\
\hline
\end{tabular}

Keterangan :

I. Skenario pembelajaran sekurang-kurangnya memuat standar kompetensi, kompotensi dasar, indikator, materi pelajaran, alat/media, sumber belajar dan penilaian.

2. Kesesuaian antara materi pelajaran dengan media dan setrategi pembelajaran

3. Kaitan antara materi pelajaran dengan pemilihan sumber belajar

4. Kesesuaian antara tujuan pembelajaran dengan sumber bahan dan penilaian.

Tabel. 3. 4. Format Penilaian Pelaksanaan Pembelajaran

\begin{tabular}{|c|c|c|c|c|c|c|c|c|}
\hline \multirow[b]{2}{*}{ NO } & \multirow[b]{2}{*}{ Nama Guru } & \multicolumn{6}{|c|}{ Aspek yang dinilai } & \multirow{2}{*}{$\begin{array}{c}\text { Jumlah } \\
\text { Skor } \\
(1-5)\end{array}$} \\
\hline & & I & 2 & 3 & 4 & 5 & 6 & \\
\hline I & SLP & & & & & & & \\
\hline 2 & PMT & & & & & & & \\
\hline 3 & ST & & & & & & & \\
\hline 4 & NST & & & & & & & \\
\hline 5 & NWY & & & & & & & \\
\hline 6 & BRD & & & & & & & \\
\hline 7 & DPA & & & & & & & \\
\hline 8 & $\mathrm{NHZ}$ & & & & & & & \\
\hline
\end{tabular}

Keterangan :

I. Kegiatan pendahuluan (apersepsi dan motivasi )

2. Kegiatan inti pelaksanaan pembelajaran secara keseluruhan

3. Kemampuan guru mengkaitkan materi pelajaran dengan lingkungan sekolah.

4. Kemampuan guru memberi contoh-contoh riil yang ada di lingkuan sekolah.

5. Kemampaun membuat evaluasi berkaitan dengan pemanfaatan lingkungan sekolah sebaga 16 belajar.

6. Penutup pelajaran (memberi penguatan, memberi $\mathrm{rK}$ tentang pemanfaatan lingkungan sekolah.)

d. Refleksi

Berdasarkan hasil observasi selama berlangsungnya kegiatan dan hasil evaluasi pada akhir pertemuan siklus dilakukan refleksi. Hasil refleksi ini dijadikan acuan untuk merencanakan penyempurnaan dan perbaikan siklus berikutnya. Semua tahap kegiatan tersebut mulai dari tahap perencanaan, pelaksanaan maupun observasi dan evaluasi dilakukan secara berulang-ulang melalui siklus-siklus sampai ada peningkatan sesuai yang diharapkan yaitu mencapai angka katagori"baik" dengan rentang skor 80 - 89. Jika skor yang diperoleh kurang dari 80-89, berarti belum memenuhi target yang ditetapkan, maka perlu bimbingan pada siklus II

2. Siklus II a. Perencanaan Penelitian.

Pada tahap ini direncanakan supervisi (pembinaan) dengan menggunakan tehnik diskusi kelompok kerja guru, tentang pemanfaatan lingkungan sekolah

sebagai sumber belajar oleh guru kelas maupun guru bidang studi di SDN 6 Raja yang belum mencapai hasil optimal dalam siklus I.

Berdasarkan hasil observasi dan refleksi siklus I,dilakukan perbaikan terhadap strategi dan penyempurnaan pelaksanaan bimbingan di siklus II.

b. Pelaksanaan Penelitian.

Pada prinsipnya langkah-langkah pelaksanaan tindakan pada siklus I

diulang pada siklus II dengan memodifikasi dan perbaikan-perbaikan berdasarkan hasil refleksi pada siklus I.

Kegiatan pada siklus II terdiri dari 2 (dua) kali pertemuan dengan mengikuti langkah-langkah sebagai berikut :

\section{I). Pertemuan I}

a). Melalui kelompok kerja, guru mendiskusikan tentang permasalahanpermasalan atau hambatan memanfaatkan lingkungan sekolah sebagai sumber belajar,dalam menyusun skenario pembelajaran yang selanjutnya dicarikan pemecahannya. Kegiatan ini dibantu oleh 
guru yang dianggap sudah cukup mampu dalam hal tersebut..

b). Guru mempresentasikan dan mensimulasikan hasil diskusi kelompoknya.

c). Guru merevisi dan menyempurnakan skenario pembelajaran dengan mengoptimalkan pemanfaatan lingkungan sekolah sebagai sumber belajar.

\section{2). Pertemuan II}

a). Guru melaksanakan kegiatan belajar mengajar di kelas dengan menggunakan skenario pembelajaran yang sudah direvisi.

b). Guru mendiskusikan dan menyempurnakan skenario pembelajaran yang lengkap dengan pemanfaatan lingkungan sekolah sebagai sumber belajar.

c). Guru mencatat kekurangan pembelajaran yang perlu diperbaiki dan disempurnakan.

c. Observasi dan Evaluasi.

Observasi dilakukan peneliti saat guru berdiskusi tentang masalah atau hambatan dan pemecahannya dalam kegiatan kelompok kerja guru baik secara individu maupun kelompok.Observasi terhadap aspek sikap guru dilakukan dengan menggunakan format observasi yang sama dengan format observasi yang digunakan pada siklus I.

Evaluasi dilakukan pada akhir pertemuan siklus II,dengan menggunakan format penilaian yang sama dengan format penilaian yang digunakan pada siklus I. Adapun aspek yang dinilai, serta cara menilai juga sama dengan penilaian pada siklus $I$.

d. Refleksi

Berdasarkan hasil observasi selama berlangsungnya kegiatan dan hasil evaluasi pada akhir pertemuan siklus II,maka dilanjutkan dengan mengadakan refleksi terhadap kegiatan dan hasil kegiatan yang sudah berlangsung.

\section{HASIL PENELITIAN DAN PEMBAHASAN}

\section{A. Hasil Penelitian}

I. Siklus I

Berdasarkan pengamatan awal di SDN 6 Raja , semua guru kelas dan guru bidang studi jarang dan bahkan tidak pernah memanfaatkan lingkungan sekolah sebagai sumber belajar,hal ini disebabkan oleh kurangnya pemahaman dan kemampuan guru untuk memanfaatkan lingkungan sekolah sebagai sumber belajar.Selama ini guru lebih banyak menggunakan buku paket dan alat peraga yang dimiliki sekolah sebagai sumber belajar untuk melengkapi kegiatan pembelajaran di kelas. Demikian pula kegiatan pembelajaran di luar kelas sangat jarang dan bahkan tidak pernah dilakukan dengan alasan tidak cukup waktu, masalah keamanan dan keselamatan siswa.Hal ini sudah tentu kurang sesuai dengan pembelajaran yang menggunakan pendekatan pembelajaran aktif,kreatif,efektif dan menyenangkan(Pakem) yang harus dilaksanakan dalam penterapan kurikulum tingkat satuan pendidikan (KTSP). Kegiatan dalam siklus I ini, diawali dengan kegiatan diskusi kelompok kerja guru (KKG) tentang permasalahan yang dihadapi dalam pemanfaatan lingkungan sekolah sebagai sumber belajar, dilanjutkan dengan informasi tentang manfaat lingkungan sekolah sebagai sumber belajar bagi siswa dan implementasinya dalam proses belajar mengajar. Saat guru berdiskusi dalam kelompok kerja guru (KKG) pada siklus I, peneliti mengadakan observasi tentang sikap guru dalam berdiskusi yang hasilnya sebagai berikut

Tabel. 4.I.I. Data Hasil Observasi

\begin{tabular}{|c|c|c|c|c|c|c|c|}
\hline \multirow{3}{*}{ No } & \multirow{3}{*}{ Nama Guru } & \multicolumn{4}{|c|}{ Aspek yang diobservasi } & \multirow{3}{*}{$\begin{array}{c}\text { Jumlah } \\
\text { Skor } \\
\text { Mak. } \\
100\end{array}$} & \multirow{3}{*}{$\begin{array}{l}\text { Kata } \\
\text { Gori }\end{array}$} \\
\hline & & Kerjasama & Aktivitas & Perhatian & Presentasi & & \\
\hline & & $(1-10)$ & $(I-40)$ & $(I-20)$ & $(1-30)$ & & \\
\hline $\mathrm{I}$ & SLP & 8 & 30 & 15 & 27 & 80 & B \\
\hline 2 & PMT & 8 & 30 & 16 & 26 & 80 & $\mathrm{~B}$ \\
\hline 3 & ST & 8 & 30 & 15 & 27 & 80 & $\mathrm{~B}$ \\
\hline 4 & NST & 8 & 30 & 15 & 27 & 80 & $\mathrm{~B}$ \\
\hline 5 & NWY & 8 & 31 & 16 & 26 & 81 & $\mathrm{~B}$ \\
\hline 6 & BRD & 8 & 33 & 16 & 22 & 79 & C \\
\hline 7 & DPA & 8 & 29 & 18 & 23 & 78 & C \\
\hline 8 & $\mathrm{NHZ}$ & 8 & 30 & 14 & 25 & 77 & C \\
\hline & Jumlah & 64 & 243 & 125 & 203 & 635 & \\
\hline & Rata-rata & 8.00 & 30.38 & 15.63 & 25.38 & 79.38 & C \\
\hline
\end{tabular}

Penilaian terhadap skenario pembelajaran dalam bentuk program perencanaan pelaksanaan pembelajaran (RPP) yang disusum guru dalam siklus I,didapatkan hasil sebagai berikut :

Tabel.4.I.2. Data Hasil Penilaian Skenario Pembelajaran

\begin{tabular}{|c|c|c|c|c|c|c|c|c|}
\hline \multirow{2}{*}{ No } & \multirow{2}{*}{ Nama Guru } & \multicolumn{4}{|c|}{ Aspek yang dinilai } & \multirow{2}{*}{$\begin{array}{l}\text { Jumlah } \\
\text { Skor }\end{array}$} & \multirow{2}{*}{$\begin{array}{c}\text { Jumlah } \\
\text { Nilai }\end{array}$} & \multirow{2}{*}{ Katagori } \\
\hline & & 1 & 2 & 3 & 4 & & & \\
\hline 1 & SLP & 4 & 4 & 4 & 5 & 17 & 85 & $\mathrm{~B}$ \\
\hline
\end{tabular}




\begin{tabular}{|l|l|c|c|c|c|c|c|c|}
\hline 2 & PMT & 5 & 4 & 4 & 3 & 16 & 80 & B \\
\hline 3 & ST & 5 & 4 & 3 & 5 & 17 & 85 & B \\
\hline 4 & NST & 4 & 4 & 4 & 5 & 17 & 85 & B \\
\hline 5 & NWY & 4 & 4 & 3 & 4 & 15 & 75 & $\mathrm{C}$ \\
\hline 6 & BRD & 4 & 4 & 3 & 4 & 15 & 75 & $\mathrm{C}$ \\
\hline 7 & DPA & 4 & 3 & 3 & 3 & 13 & 65 & $\mathrm{C}$ \\
\hline 8 & NHZ & 5 & 4 & 3 & 4 & 16 & 80 & $\mathrm{~B}$ \\
\hline \multicolumn{2}{r|}{ Jumlah } & 34 & 31 & 28 & 33 & 126 & 630 & \\
\hline \multicolumn{2}{r|}{ Rata-rata } & 4.25 & 3.88 & 3.50 & 4.13 & 15.75 & 78.75 & $\mathrm{C}$ \\
\hline
\end{tabular}

Sedangkan penilaian implementasi pemanfaatan lingkungan sekolah sebagai sumber belajar dalam kegiatan pembelajaran di kelas pada siklus I didapatkan hasil sebagai berikut :

Tabel.4.I.3. Data Hasil Penilaian Pelaksanaan Pembelajaran

\begin{tabular}{|c|c|c|c|c|c|c|c|c|c|c|}
\hline \multirow{2}{*}{ No } & \multirow{2}{*}{ Nama Guru } & \multicolumn{6}{|c|}{ Aspek yang dinilai } & \multirow{2}{*}{$\begin{array}{l}\text { Jumlah } \\
\text { Skor }\end{array}$} & \multirow{2}{*}{$\begin{array}{c}\text { Jumlah } \\
\text { Nilai }\end{array}$} & \multirow{2}{*}{$\begin{array}{l}\text { Kata } \\
\text { gori }\end{array}$} \\
\hline & & I & 2 & 3 & 4 & 5 & 6 & & & \\
\hline I & SLP & 5 & 4 & 5 & 4 & 4 & 4 & 26 & 86.67 & B \\
\hline 2 & PMT & 4 & 3 & 4 & 4 & 3 & 4 & 22 & 73.33 & C \\
\hline 3 & ST & 5 & 4 & 4 & 4 & 5 & 5 & 27 & 90.00 & $A$ \\
\hline 4 & NST & 4 & 3 & 4 & 4 & 3 & 4 & 22 & 73.33 & $C$ \\
\hline 5 & NWY & 4 & 3 & 4 & 3 & 4 & 3 & 21 & 70.00 & C \\
\hline 6 & BRD & 5 & 4 & 4 & 4 & 4 & 5 & 26 & 86.67 & B \\
\hline 7 & DPA & 4 & 3 & 3 & 4 & 3 & 3 & 20 & 66.66 & C \\
\hline 8 & $\mathrm{NHZ}$ & 4 & 4 & 4 & 4 & 4 & 4 & 24 & 80.00 & $\mathrm{~B}$ \\
\hline \multicolumn{2}{|r|}{ Jumlah } & 34 & 28 & 32 & 32 & 30 & 32 & 188 & 626.67 & \\
\hline \multicolumn{2}{|r|}{ Rata-rata } & 4.25 & 3.5 & 4 & 4 & 3.75 & 4 & 23.5 & 78.33 & C \\
\hline
\end{tabular}

Data penelitian tindakan sekolah yang diperoleh dari hasil observasi sikap guru dalam kegiatan diskusi kelompok kerja guru tentang pemanfaatan lingkungan sekolah sebagai sumber belajar pada siklus I, hasilnya termasuk katagori “cukup" dengan rata-rata nilai 79,38. Hal ini menunjukkan bahwa guru dalam berdiskusi belum menampakkan kerjasama,aktivitas dan perhatian yang baik terhadap permasalahan pemanfaatan lingkungan sekolah sebagai sumber belajar ,sehingga diperlukan bimbingan yang lebih intensif.

Penilaian implementasi pemanfaatan lingkungan sekolah sebagai sumber belajar dalam kegiatan pembelajaran di kelas, hasilnya termasuk katagori "cukup" dengan rata-rata nilai 78.33. Hal ini menunjukkan bahwa guru dalam mengimplementasikan pemanfaatan lingkungan sekolah sebagai sumber belajar melalui kegiatan pembelajaran di kelas belum optimal,sehingga perlu peningkatan.

Dengan adanya hasil observasi dan penilaian pada kegiatan siklusl maka peneliti melakukan refleksi. Dari refleksi terhadap seluruh kegiatan pada siklus I, maka ditemukan beberapa hambatan yang mengakibatkan belum optimalnya kemampuan guru memanfaatkan lingkungan sekolah sebagai sumber belajar.

Adapun hambatan-hambatan tersebut,antara lain guru belum sepenuhnya memahami manfaat lingkungan sekolah sebagai sumber belajar, dan guru dalam memilih sumber belajar dan memilih strategi pembelajaran dengan memanfaatkan lingkungan sekolah belum sesuai dengan yang diharapkan. Hal ini terlihat dalam skenario pembelajaran guru pada: aspek I. jenis sumber belajar dari lingkungan sekolah tidak tercantum, padahal materi pelajaran ada kaitannya dengan lingkungan sekolah;. aspek 2. Kesesuaian antara materi pelajaran dengan media dan setrategi pembelajaran masih kurang; aspek 4. Kesesuaian antara tujuan pembelajaran dengan sumber bahan,lebih banyak hanya mencantumkan buku paket sebagai satu-satunya sumber belajar.

Dari hasil refleksi pelaksanaan pembelajaran di kelas, hambatan-hambatan yang ditemukan adalah sebagai berikut : aspek I.dalam kegiatan awal,guru tidak memberi informasi tujuan pembelajaran dan waktunya belum sesuai dengan perencanaan; aspek 2. kegiatan inti, langkah - langkah pembelajaran masih didominasi guru dengan metode ceramah sehingga kurang sesuai dengan pembelajaran aktif,kreatif,efektip dan menyenangkan (Pakem);aspek 3. Kemampuan guru mengkaitkan materi pelajaran dengan lingkungan sekolah belum optimal; aspek 6 . Penutup pelajaran, guru kurang memberi penekanan tentang lingkungan sekolah. Hambatan-hambatan tersebut akan disempurnakan pada kegiatan siklus II.

2. Siklus II.

Pada siklus II, kegiatan yang dilaksanakan adalah mendiskusikan hambatan- hambatan yang dialami dalam menyusun skenario pembelajaran dan pelaksanaan pembelajaran di kelas pada siklus I melalui kegiatan kelompok kerja guru (KKG). Adapun secara rinci uraian kegiatannya sebagai berikut :

Dalam penyusunan skenario pembelajaran khususnya pada aspek I, 2 dan 4 guru melakukan revisi, dipandu oleh guru yang sudah mampu,dengan bimbingan peneliti/pengawas. Dalam pelaksanaan pembelajaran di kelas,terkait dengan hambatan pada aspek I. kegiatan awal, aspek 2. kegiatan inti, aspek 3. kemampuan guru mengkaitkan materi pelajaran dengan lingkungan sekolah ,dan aspek 6 . penutup 
pelajaran, maka guru mendiskusikan kembali hambatan tersebut dalam kelompok kerja guru (KKG) dibimbing pengawas/peneliti. Sebelum pelaksanaan pembelajaran di kelas, terlebih dahulu dilakukan simulasi atau modeling dengan menggunakan anggota kelompok guru sebagai siswa.
Sebagaimana kegiatan peneliti pada siklus I, maka kegiatan pada siklus keduapun dilakukan observasi,evaluasi dan penilaian. Hasil observasi terhadap sikap guru dalam berdiskusi pada siklus II dapat disajikan sebagai berikut :

Tabel. 4.2.I. Data Hasil Observasi

\begin{tabular}{|c|c|c|c|c|c|c|c|}
\hline \multirow{3}{*}{ No } & \multirow{3}{*}{ Nama Guru } & \multicolumn{4}{|c|}{ Aspek yang diobservasi } & \multirow{3}{*}{$\begin{array}{l}\text { Jumlah } \\
\text { Skor } \\
\text { Mak. } 100\end{array}$} & \multirow{3}{*}{$\begin{array}{l}\text { Kata } \\
\text { Gori }\end{array}$} \\
\hline & & Kerjasama & Aktivitas & Perhatian & Presentasi & & \\
\hline & & $(1-10)$ & $(I-40)$ & $(I-20)$ & $(I-30)$ & & \\
\hline 1 & SLP & 8 & 35 & 15 & 28 & 86 & $B$ \\
\hline 2 & PMT & 8 & 33 & 16 & 26 & 83 & B \\
\hline 3 & ST & 8 & 38 & 18 & 28 & 92 & $\mathrm{~A}$ \\
\hline 4 & NST & 8 & 35 & 15 & 27 & 85 & B \\
\hline 5 & NWY & 8 & 32 & 16 & 26 & 82 & $B$ \\
\hline 6 & BRD & 8 & 33 & 16 & 26 & 83 & $B$ \\
\hline 7 & DPA & 8 & 36 & 15 & 27 & 86 & B \\
\hline 8 & $\mathrm{NHZ}$ & 8 & 34 & 14 & 26 & 82 & B \\
\hline & Jumlah & 64 & 276 & 125 & 214 & 679 & \\
\hline & Rata-rata & 8.00 & 34.50 & 15.63 & 26.75 & 84.88 & B \\
\hline
\end{tabular}

Hasil penilaian terhadap skenario pembelajaran dalam bentuk rencana pelaksanaan pembelajaran(RPP) dapat disajikan sebagai berikut :

Tabel.4.2.2. Data Hasil Penilaian Skenario Pembelajaran

\begin{tabular}{|c|c|c|c|c|c|c|c|c|}
\hline \multirow{2}{*}{ No } & \multirow{2}{*}{ Nama Guru } & \multicolumn{4}{|c|}{ Aspek yang dinilai } & \multirow{2}{*}{$\begin{array}{l}\text { Jumlah } \\
\text { Skor }\end{array}$} & \multirow{2}{*}{$\begin{array}{l}\text { Jumlah } \\
\text { Nilai }\end{array}$} & \multirow{2}{*}{$\begin{array}{c}\text { Katago } \\
\mathrm{ri}\end{array}$} \\
\hline & & $\mathrm{I}$ & 2 & 3 & 4 & & & \\
\hline $\mathrm{I}$ & SLP & 4 & 4 & 4 & 5 & 17 & 85 & B \\
\hline 2 & PMT & 5 & 4 & 4 & 4 & 17 & 85 & $B$ \\
\hline 3 & ST & 4 & 4 & 4 & 5 & 17 & 85 & B \\
\hline 4 & NST & 4 & 4 & 4 & 5 & 17 & 85 & B \\
\hline 5 & NWY & 4 & 4 & 4 & 4 & 16 & 80 & B \\
\hline 6 & BRD & 4 & 4 & 4 & 4 & 16 & 80 & B \\
\hline 7 & DPA & 4 & 4 & 4 & 4 & 16 & 80 & B \\
\hline 8 & $\mathrm{NHZ}$ & 4 & 4 & 4 & 4 & 16 & 80 & B \\
\hline & Jumlah & 35 & 32 & 30 & 35 & 132 & 660 & \\
\hline & Rata-rata & 4.38 & 4.00 & 3.75 & 4.38 & 16.50 & 82.50 & B \\
\hline
\end{tabular}

Hasil penilaian terhadap Pelaksanaan Pembelajaran dapat disajikan sebagai berikut:

Tabel.4.2.3. Data Hasil Penilaian Pelaksanaan Pembelajaran

\begin{tabular}{|c|c|c|c|c|c|c|c|c|c|c|}
\hline \multirow{2}{*}{ No } & \multirow{2}{*}{ Nama Guru } & \multicolumn{6}{|c|}{ Aspek yang dinilai } & \multirow{2}{*}{$\begin{array}{l}\text { Jumlah } \\
\text { Skor }\end{array}$} & \multirow{2}{*}{$\begin{array}{l}\text { Jumlah } \\
\text { Nilai }\end{array}$} & \multirow{2}{*}{$\begin{array}{l}\text { Kata } \\
\text { gori }\end{array}$} \\
\hline & & I & 2 & 3 & 4 & 5 & 6 & & & \\
\hline I & SLP & 5 & 4 & 5 & 4 & 4 & 4 & 26 & 86.67 & $B$ \\
\hline 2 & PMT & 4 & 4 & 4 & 4 & 4 & 4 & 24 & 80.00 & $B$ \\
\hline 3 & ST & 5 & 4 & 4 & 5 & 4 & 5 & 27 & 90.00 & $\mathrm{~A}$ \\
\hline 4 & NST & 4 & 3 & 4 & 4 & 4 & 4 & 23 & 76.67 & C \\
\hline 5 & NWY & 4 & 4 & 4 & 4 & 4 & 4 & 24 & 80.00 & $B$ \\
\hline 6 & BRD & 5 & 4 & 4 & 4 & 4 & 5 & 26 & 86.67 & B \\
\hline 7 & DPA & 4 & 4 & 4 & 4 & 4 & 4 & 24 & 73.33 & C \\
\hline 8 & $\mathrm{NHZ}$ & 4 & 4 & 4 & 4 & 4 & 4 & 24 & 80.00 & $B$ \\
\hline \multicolumn{2}{|r|}{ Jumlah } & 35 & 30 & 33 & 33 & 32 & 34 & 197 & 656.67 & \\
\hline \multicolumn{2}{|r|}{ Rata-rata } & 4.38 & 3.75 & 4.13 & 4.13 & 4.00 & 4.25 & 24.63 & 82.08 & $B$ \\
\hline
\end{tabular}

Data yang diperoleh dari observasi sikap guru pada siklus II, setelah dianalisis ada peningkatan kearah perbaikan yaitu berada pada katagori "baik", dengan rata-rata nilai 84.88. Sedangkan untuk penilaian skenario pembelajaran dan penilaian pelaksanaan pembelajaran,masing-masing juga ada peningkatan yang ke arah yang lebih baik yaitu: untuk skenario pembelajaran berada pada katagori "baik" dengan nilai rata-rata 82.50 , dan untuk penilaian pelaksanaan pembelajaran di kelas berada pada katagori "baik" dengan nilai rata-rata 82.08. Dengan melihat hasil pada siklus II, maka refleksi terhadap hasil yang diperoleh peneliti pada siklus II ini adalah adanya peningkatan kemampuan guru memanfaatkan lingkungan sekolah sebagai sumber belajar. $\mathrm{Hal}$ ini dibuktikan dengan nilai rata-rata yang diperoleh dalam memprogramkan pembelajaran serta dalam implementasinya di kelas yang sudah menunjukkan adanya peningkatan kemampuan guru untuk memanfaatkan lingkungan sekolah sebagai sumber belajar yang lebih baik.Sedangkan dari jumlah guru ,75\% sudah mencapai kriteria yang ditetapkan. 


\section{B. Pembahasan.}

Dari 8 orang guru yang terlibat, 5 orang guru sudah mendapat skor dengan katagori "baik" sedangkan 3 orang dengan katagori "cukup". Oleh karena itu dilanjutkan dengan tindakan siklus II yang hasilnya secara umum ada peningkatan ke arah yang lebih baik yaitu $75 \%$ guru sudah mendapatkan katagori baik dengan skor ratarata 80 - 89. Hal ini sudah sesuai dengan kriteria keberhasilan yang ditetapkan. Secara rinci perolehan nilai rata-rata peningkatan kemampuan guru memanfaatkan lingkungan sekolah sebagai sumber belajar yaitu nilai ratarata observasi hasil kegiatan diskusi 79,38 di siklus I menjadi 84,88 di siklus II ada peningkatan 5,5. kegiatan penyusunan skenario pembelajaran nilai rata-rata 78,75 di siklus I menjadi 82,50 di siklus II ada peningkatan 3,75, kegiatan pembelajaran atau dalam proses belajar mengajar nilai rata-rata 78,33 di sklus I menjadi 82,08 di siklus II, ada peningkatan 3,75 .

\section{A. Kesimpulan}

\section{KESIMPULAN DAN SARAN}

Berdasarkan hasil analisis dan pembahasan siklus I dan siklus II tersebut di atas, maka dapat disimpulkan bahwa:

I. Ada peningkatan kemampuan guru dalam memanfaatkan lingkungan sekolah sebagai sumber belajar melalui pendekatan diskusi kelompok kerja guru (KKG) di SDN 6 Raja

2. Hasil pada setiap siklus adalah nilai rata-rata observasi hasil kegiatan diskusi 79,38 di siklus I menjadi 84,88 di siklus II ada peningkatan 5,5. kegiatan penyusunan skenario pembelajaran nilai rata-rata 78,75 di siklus I menjadi 82,50 di siklus II ada peningkatan 3,75, kegiatan pembelajaran atau dalam proses belajar mengajar nilai rata-rata $78,33 \mathrm{di}$ sklus I menjadi 82,08 di siklus II, ada peningkatan 3,75 .
B. Saran

Dari simpulan tersebut di atas, disarankan :

I. Kepada.guru-guru khususnya guru di SDN 6 Raja , di dalam menyusun skenario pembelajaran agar memanfaatkan semaksimal mungkin lingkungan sekolah dan lingkungan siswa yang sesuai dengan materi pembelajaran sebagai sumber belajar,dan mengintensifkan diskusi KKG dalam memecahkan masalah yang dihadapi.

\section{DAFTAR PUSTAKA}

Badru Zaman, dkk. 2009. Media dan Sumber Belajar TK. Buku Materi Pokok PGTK 2304. Modul I-9. Jakarta Universiats Terbuka.

Ekowati, Endang. 200I. Stategi Pembelajaran Kooperatif. Modul Pelatihan Guru Terintegrasi Berbasis Kompetensi. Jakarta : Depdiknas.

Kasianto, I Wayan 2004, Meningkatkan Prestasi Belajar Siswa dengan Pendekatan Diskusi Kelompok. Laporan Penelitian Kelas. Tidak dipublikasikan

Kemmis, S., McTaggart, R., \& Nixon, R. 2000. The Action research Planner. (doing Critical Participatory Action research). Singapura: Springer.

Rusyan Tabrani. 200I. Pendekatan dalam Proses Belajar Mengajar. Bandung Remaja Rosdakarya.

Sarman, 2005, Metode Penelitian Kualitatif, Jakarta, Rineka Cipta.

Sarman, Samsuni S.Pd. 2005. Implementasi Pendekatan Works Based Learning pada Sumber Belajar Masyarakat dalam Pembelajaran PS-Ekonomi. Laporan Penelitian Tindakan Kelas. Banjarmasin. Tidak dipublikasikan.

Sutrisno Hadi, 2000. Metodelogi Penelitian. Yogyakarta : Andi

SW, Ischak dan Warji R. 1987. Program Remedial dalam. Proses Belajar Mengajar. Yogyakarta: Liberty.

Tabrani dan. Daryani dalam. Kasianto,2004, Memanfaatkan Lingkungan Sekolah Sebagai Sumber Belajar, bandung, Remaja Rosda Karya. 